\title{
$\mathrm{X}$ 線吸収分光（XAS）による反応観察
}

\author{
木 村 正 雄 ${ }^{*}, * 2$
}

\section{Observation of Reactions using X-ray Absorption Spectroscopy (XAS) Masao KIMURA*1,*2}

${ }^{* 1}$ Photon Factory (PF), Institute of Materials Structure Science (IMSS) High Energy Accelerator Research Organization (KEK), 1-1 Oho, Tsukuba-shi, Ibaraki 305-0801, Japan

${ }^{*}$ Dept. Materials Structure Science, School of High Energy Accelerator Sci., SOKENDAI (The Graduate University for Advanced Studies), 1-1 Oho, Tsukuba-shi, Ibaraki 305-0801, Japan

(Received July 7, 2016, Accepted September 21, 2016)

\begin{abstract}
Application of X-ray Absorption Spectroscopy (XAS) to observation of various reactions is reviewed. XAS is a unique tool for studying the local structure around a selected element at atomic scale. XAS can be applied to materials such as crystals, amorphous systems, and liquids, which are situated in various conditions (in gas, at high temperature, with an applied stress, $\cdots$ ). Thus XAS is one of the most powerful techniques to investigate the structure change of materials during reactions and understand the mechanism. In this paper, some of typical examples-redox of catalyst, corrosion of steel, heterogeneous reduction of oxides-are shown and their key points are discussed.
\end{abstract}

\section{1.はじめに}

材料をある環境下（高温, ガス中, 応力印加, 電場印加, …) におくと，時間と共に材料中に変化が生じる．その変化 一特に原子レベルの構造の变化一を時系列観察することが 「反応を観察する」のひとつである（Fig. 1). それにより， 材料の製造プロセスの開発, 供与環境での機能発現のメカニ ズム解明, 長期使用に伴う劣化現象の解明, 等, 材料の一生 を理解し制御するための知見が得られる.

「反応を観察する」ためには，「反応条件」，「時間」，「計測」 の 3 つの軸で, 材料中の構造の変化を観察することが必要 になる. 具体的に反応を観察するためには様々な計測手法が あり，本稿で取り上げるX-ray Absorption Spectroscopy (XAS) (X-ray Absorption Fine Structures (XAFS))では, エネルギーの異なる X 線の吸収率を測定する。つまり, XASによる観測では「計測」の軸とは, 吸収率の依存性を 測定するエネルギ一軸になる，なお，「反応条件」と「時間」 を重視して観察を行うのは所謂「その場 (in situ) 観察」も しくは「オペランド (operando) 観察」と呼ばれる. 後者 は，材料が実際に機能していることを確認しながら観察を行 うことを強調した表現である。

反応に伴う構造の変化は多くの場合材料中で不均一である ことがほとんどであるので, 実際には,「反応条件」,「時 間」，「計測（XAS ではエネルギー軸）」の3つにさらに， 「空間 (3 次元)」を加えた 6 次元で観察を行うことが理想と なる (Fig. 1).

もちろん対象とする反応により, 簡便な測定で目的を達成 できる場合もある. 例えば, 試料内での反応が均一に進行 し，ある状態を凍結（例えば高温からの急冷）ができる場合

*1 高エネルギー加速器研究機構, 物質構造科学研究所 (下3050801 茨城県つくば市大穂 $1-1$ )

*2 総合研究大学院大学 (総研大), 高エネルギー加速器科学研究 科, 物質構造科学専攻（干305-0801 茨城県つくば市大穂 1-1）

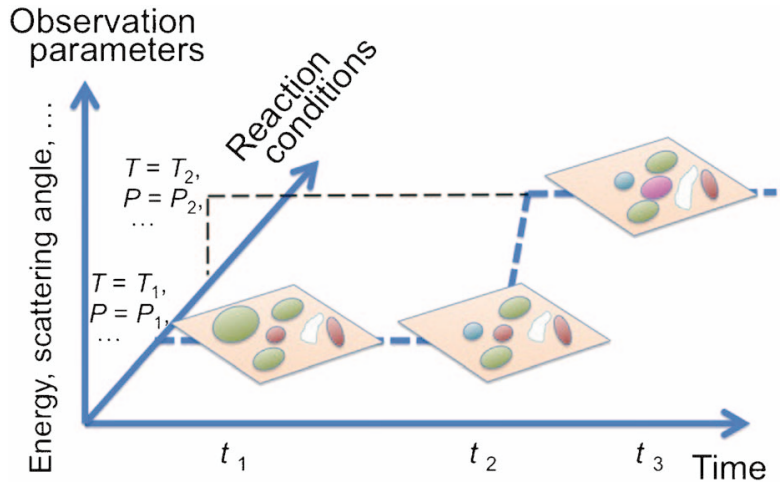

Fig. 1 (Color online) The six-dimensional (6D) approach to in situ (or operando) observation of various reactions.

には，凍結した試料全平均について測定を行えば良い。つま り,「反応条件」と「計測 (エネルギー軸)」の 2 次元の観 察でよい.しかし, 材料の不均一性 (heterogeneity) や表 面/界面を活用した材料設計や，そうした系での反応メカ二 ズムを解明していくためには, 究極の 6 次元での観察が不 可欠となるケースも多々ある，そうした材料の進化に対応し て, 放射光やXFEL といった高度計測のための施設の整備 が進んでいる．その結果，究極の 6 次元での観察が実現可 能なレベルになり，急速に様々な分野に広がりつつある.

そこで本稿では,「反応条件」,「時間」,「計測」,「空間 (3 次元)」の視点から, XAS を使った反応観察の例を紹介 し，それぞれの次元（因子）のポイントを述べたい，そして 最後に究極の 6 次元に向けた計測についても触れたい.

\section{2. 排ガス浄化触媒の酸化還元反応観察}

「反応条件」「時間」「計測 (エネルギー軸)」の 3 次元を 同時に測定する典型的な例として, 排ガス浄化触媒の酸化還 元反応を DXAFS (Dispersive XAFS) 法1,2)により観察した 例を紹介する，DXAFS 法では，広範囲のエネルギーを含む 
X 線ビーム（白色ビーム）を光学素子で試料に集光する (Fig. 2). 試料を透過した発散 X 線を一次元型検出器で測 定することにより，異なるエネルギーでの透過率一即ち XAS スペクトルを“すべてのエネルギーで同時”に測定す ることができる，反応観察の「計測」の際にエネルギー等を “掃引（スキャン）”すると，その間に反応が進行する恐れが ある. そのため, “掃引 (スキャン)” 無しに全てのエネルギー を“同時”に計測することは，反応観察のための基本的な要 件となる.（DXAS や触媒反応観察の詳細については本特集 内で別途詳細に解説があるので, 本稿では概要にとどめる.)

エンジンからの排ガス中に含をれる $\mathrm{NO}_{\mathrm{x}}, \mathrm{SO}_{\mathrm{x}}, \mathrm{CO}$ 等の物 質を含有するガスの浄化を高効率に行うことは，環境負荷を 低減するための重要な技術である。そのためには，安価・高 効率・長寿命の条件を満たす触媒開発が重要となる。一般的 なガソリンエンジンは, 空気/然料比率が化学両論比に近い 環境で使用されるが，運転状況によって排ガスは酸化䨌囲気 （未反応空気が残る）と還元䨌囲気（未反応燃料が残る）の 間を秒単位で変化する，そのため, 実環境での排ガス浄化触 媒の挙動を原子レベルで観察するためには, ガス䨌囲気下で

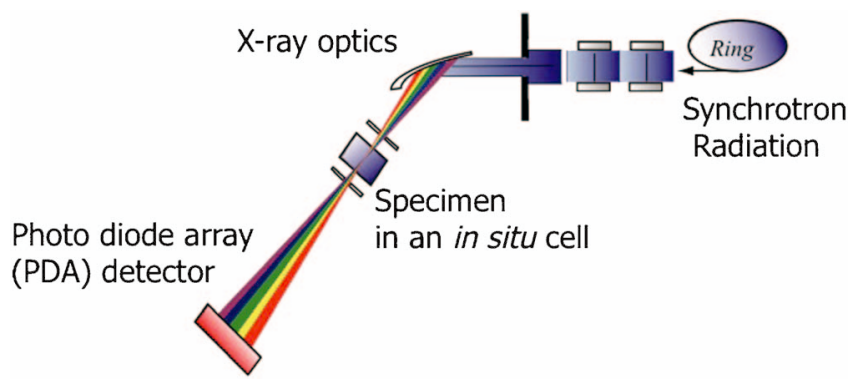

Fig. 2 (Color online) Outline of the experimental setup of DXAFS.

(a)

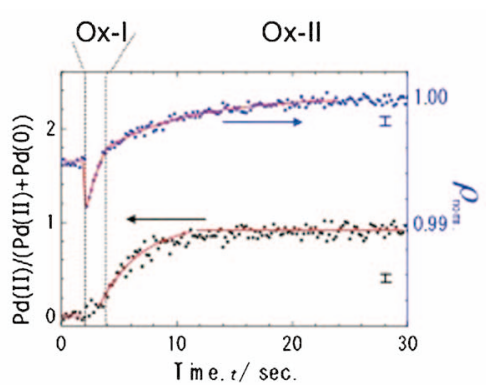

(b)

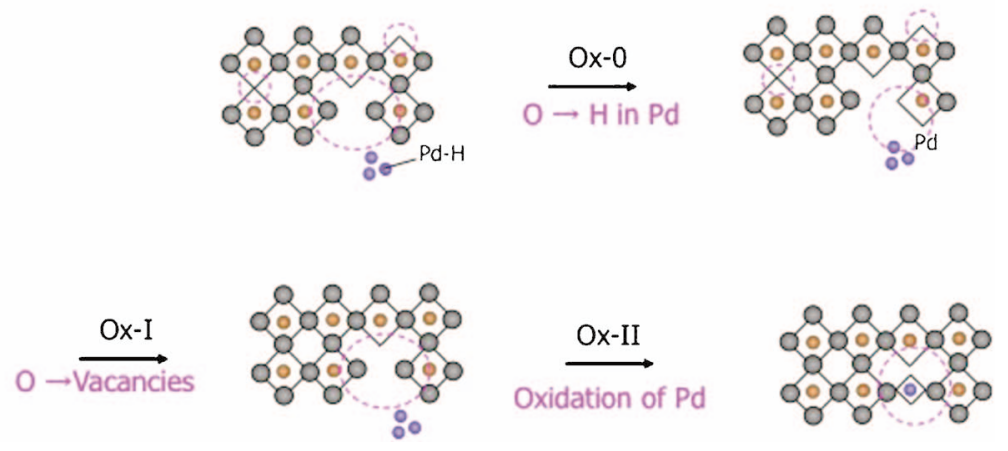

Fig. 4 (Color online) (a) Change of the ratio of $\mathrm{Pd} /\left(\mathrm{Pd}^{\mathrm{II}}+\mathrm{Pd}^{0}\right)$ as a function of the reaction time, and (b) schematic diagram of change in the structure of $\mathrm{Pd} / \mathrm{Al}_{2} \mathrm{O}_{3}$ catalyst during oxidation.
サブ秒の時間分解能をもった観察技術が必要となり， DXAFS 法を用いた反応観察を実施した。「エンジンからの 排ガス成分の変化に応じて触媒中の活性貴金属元素の状態が 変化する過程」を，数 $10 \mathrm{~ms}$ の短時間で in situ 観察するこ とに成功した ${ }^{3)}$. モデル的試料である $\mathrm{Pd} / \mathrm{Al}_{2} \mathrm{O}_{3}$ の還元反応 の観察例を Fig. 3 に示す.

こうした観察により，酸化還元反応に伴う構造变化が解明 され, 反応速度論の観点から反応メカニズムに関する知見を 得た ${ }^{4)}$. 酸化反応の際の全 $\mathrm{Pd}$ 中の $\mathrm{Pd}^{\mathrm{II}}$ の比率と反応に伴う 触媒の原子ベルの構造変化, 即ち Pd の価数と酸素欠陥濃度 の变化（Fig. 4 (a) ) を定量的に測定し，その反応モデル (Fig. 4(b)）を解明することができた. 酸素ガス導入直後の $t=0 \sim 0.2 \mathrm{sec}$ に（直前の還元サイクルで） Pdに吸蔵されて

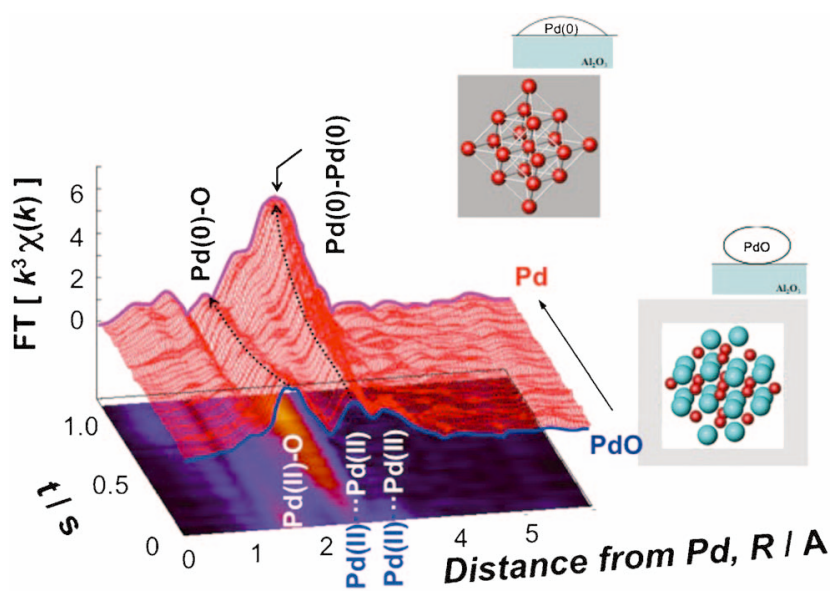

Fig. 3 (Color online) Change of the local structure around $\mathrm{Pd}$ supported on $\mathrm{Al}_{2} \mathrm{O}_{3}$ substrate during reduction. Fourier transforms (FTs) of EXAFS data $k^{3} \chi(k)$ are plotted as a function of the reaction time. 
いた水素が除かれる反応の後, 触媒担体のペロブスカイト酸 化物中の酸素欠陥が急激に回復する反応 $(\mathrm{Ox}-\mathrm{I})$ が進行す る. その後, $t=2.0 \sim 11.0 \mathrm{sec}$ の時間帯に $\mathrm{Pd}$ の酸化が進行 すると共に, 酸素欠損がさらにさらに現象していく．こうし た多段階反応は, 触媒担体のペロブスカイト酸化物と $\mathrm{Pd}$ 粒 がナノレベルで混在した構造であることを示して抢り，そう した構造が Pdの凝集を抑制して, 少量の Pdでも高い触媒 活性を示すことが期待できる4)。こうしたメカニズムに立脚 して，排ガス浄化特性に優れた触媒の設計指針として，(a) 排ガス中の酸素ポテンシャルに対応して $\mathrm{Pd}$ ナ粒子が生成 せ消滅する，(b)その反応を短時間かつ可逆的に進行させる ための酸素原子の出入りが容易な結晶構造を有する担体，を 提案した。こうした指針をもとに，新たな $\mathrm{Fe}$ 系排ガス浄化 触媒が開発され貴金属量の低減効果が確認された ${ }^{5)}$.

こうした時分割測定の分析技術は，msレベルであれば様 々な反応に適用可能なレベルになっている.この時間域は原 子や分子の拡散に伴う反応に相当するため, 様々な反応系に 適用可能である. そのためこうした時分割測定はこれから様 々な材料・反応系に広がっていくと考えられる。

さらに短時間の反応観察についても研究が進んでいる. 反 応系や試料の形態が限定されるが, 光励起反応といった可逆 反応系（繰り返し可能な反応）では, 繰り返し観察した結果 を積算して $\mathrm{S} / \mathrm{N}$ 比を高めることにより $\mathrm{fs} \sim \mathrm{ps}$ といった極短 時間の時間分解能での測定が可能になっている. 例えば溶液 分散している光励起の可逆反応系（繰り返し可能な反応）で あればfs, ps での測定が可能になっている6).こうした時分 割測定の多くは, 光やガスの導入といったトリガーを反応の 起点として極短時間後の反応を観察するものである.

一方，不可逆反応の観察でも，工夫によりさらに短時間の 観察が可能である. 上述した触媒の例のように, 実際の材料 系では, 「反応条件」を同様に制御しても, 繰り返し反応す ると劣化等の現象が観察される等, 厳密な意味では同じ反応 が進行するとは限らないケースも多い。例えば，材料の破壊 や劣化といった現象が代表的なものである.このような一度 の測定でデータを得るしかない不可逆な反応系でも, 工夫す
ることにより上述した触媒の例 $(\mathrm{ms})$ よりもさらに時間分 解能を向上させた測定ができる．例えば，放射光のパルス性 （一定の時間間隔で X 線が発生する）を利用して，X 線が発 生するタイミングに合わせてレーザー照射するシステム ${ }^{7,8)}$ (Fig. 5) により不可逆反応の観察が可能である. そのシス テムにより例えばレーザー圧縮にともなう構造の変化の観察 を ns の時間スケールで in situ 測定可能となっている8). 今 後こうした観察法は，破壊や相転移といった，多くの材料に 共通する基本的現象（不可逆反応）のリアルタイム観察も可 能になることが期待できる.

\section{3. 耐候性鋼の大気腐食反応の観察}

反応を明らかにするためには複数の「計測」を行う必要が あるケースも多い.XAS 法では材料中特定元素の原子周り の局所構造，すなわち short-range order（SRO）の情報に 限られる.そのため, 複数の相補的な「計測」手法を用いて 反応観察を行うことがそのメカニズム解明のために必要とな る場合があり，本節ではその例として鉄鋼の大気腐食の反応 観察の例を紹介する.

鉄はすぐさびる…思われているが，工夫することに より実用に耐える耐大気腐食性を付与することができる．耐 候性鋼と呼ばれる低合金耐食鋼は，鋼中への 1 mass.\%以下 の僅かな量の $\mathrm{Cu}, \mathrm{Cr}$ の添加により耐候性（＝屋外大気中で の耐食性）が向上する. その理由として耐候性鋼を大気中で 使用すると数年のうちに表面に緻密なさび層が形成され，酸 素や水分の地鉄へ進入が低減しそれ以降の腐食速度が低下す ると考えられている. しかし，なぜわずかな元素添加により さびが緻密化するかについては 30 年以上不明であった。こ れは，実際に腐食が進行する環境（塩分を含む水分に濡れた 状態せ乾燥した状態の繰り返しサイクル）で，特定の添加元 素がどのように作用しているかをin situ 観察することが困 難であったからである.

そこで放射光を用いた湿潤環境を再現する反応セル（Fig. 6(a)）を用いて，大気腐食の反応観察を実施した ${ }^{9)}$. 反応を 「計測」するために, XASにより添加元素のSRO の情報と,

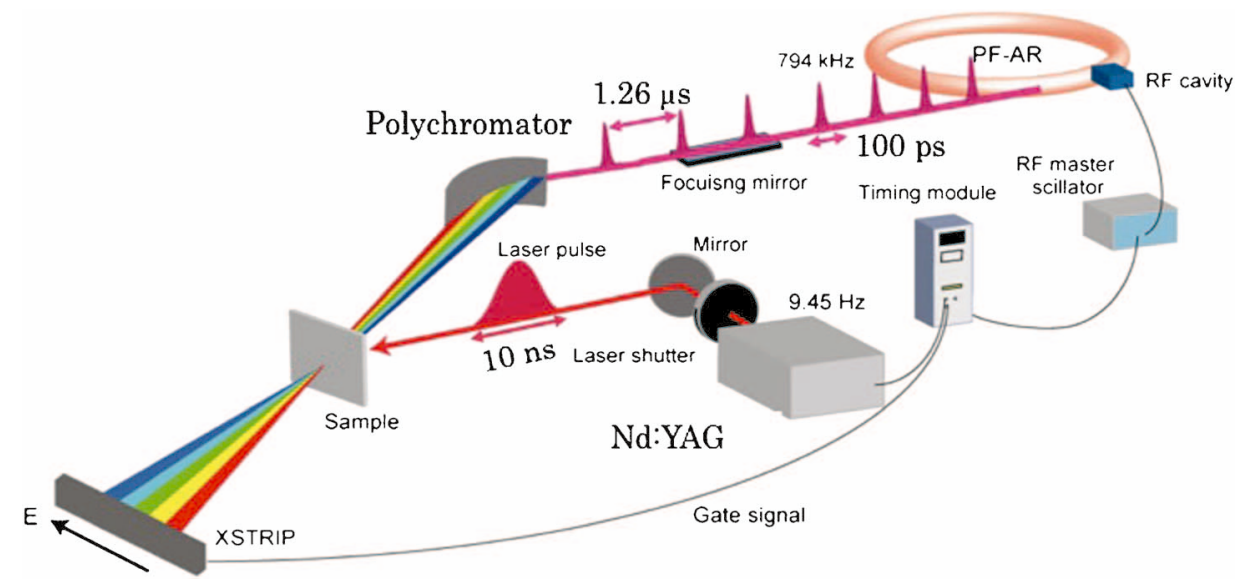

Fig. 5 (Color online) Schematic diagram of a developed system to investigate the time-evolution of structure after laser shock using DXAFS at NW2A of the PF-AR in KEK ${ }^{7,8}$. The change of structure in specimen after laser-shock is measured by DXAFS, where a spectrum covering the full energy range of interest can be obtained at once using a bent crystal (polychrometor) at once without any mechanical movements. A time-resolution in order of ns can be achieved by controlling the timing between the laser pulse, and the X-ray one. 
XRD の一つの手法である異常散乱法による long-range order（LRO）の情報を合わせて計測した（Fig. 6(a)). どちら の手法も, $\mathrm{X}$ 線のエネルギーを元素特有の吸収エネルギー にチューニングすることにより特定の添加元素の構造情報を 得るものである. 電子顕微鏡でも電子線を照射した際に発生 する蛍光 X 線を用いて元素の種類・量を測定可能であるが， X-ray in \& X-ray outの条件ではさらにその元素のナノレ ベルの原子情報を得られるのが放射光を用いたin situ 観察 の大きな特徵である.

その結果,「腐食初期に生成するコロイド状さび $\rightarrow$ 乾燥後 の微結晶さび（結晶サイズ〜数 $\mathrm{nm}$ )」の反応を直接観察し, その原子構造変化から添加元素の及ぼす反応メカニズム (Fig. 7 $)^{9,10)}$ を解明することに成功した. 金属添加元素の無 い炭素鋼では腐食速度が速くさび $(\mathrm{FeOOH})$ の結晶粒が急
速に発達し粗大なさび層が形成される. $\mathrm{Cr}, \mathrm{Cu}$ を微量に添 加すると, それらが起点となってさびの結晶粒が微細化し, 緻密なさび層が形成される. そのため, 水分等の腐食を加速 する化学種が外界から地鉄界面に（粒界）拡散しづらくなっ てある程度の耐食性を示す，微量な Ni を添加して緻密なさ び層の表面電荷を正から負にすると, 塩化物イオンの侵入も 低減し, 海岸近くのより過酷な環境でも耐食性を示すことが 科学的に立証された.

こうしたメカニズムに立脚して, 大気腐食性に優れた材料 の設計指針として，(a)コロイド科学的視点から生成する腐 食生成物と地鉄との界面での $\mathrm{pH}$ の低下を防止する，(b) $\mathrm{H}^{+}, \mathrm{Cl}^{-}$イオン等の界面への拡散を妨げる，を提案した ${ }^{11)}$. こうした考えは新たに開発された $\mathrm{Ni}$ 高耐候性鋼で実現化さ れ，さらに寿命予測技術や保守/補修技術を含めた総合的な (a)

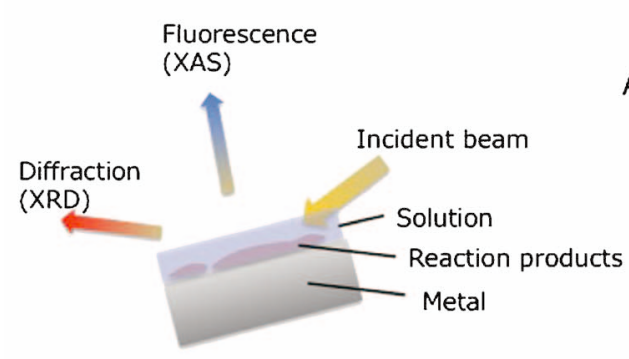

(b)

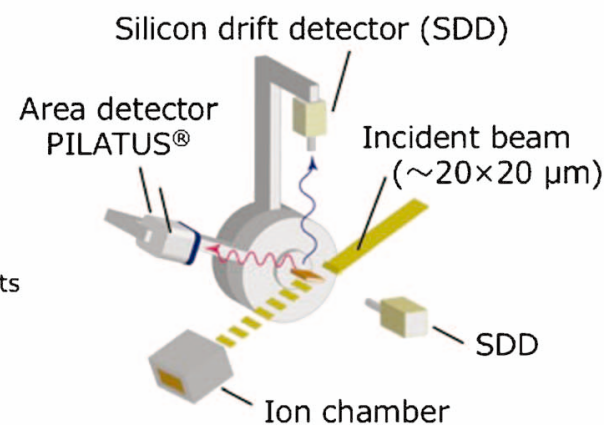

Fig. 6 (Color online) Experimental setups for simultaneous observation using different techniques. (a) In situ observation of corrosion using XAS, and XRD, and (b) two-dimmensional mapping of chemical states using XAS, and XRD (at BL-15A1 in PF, KEK).

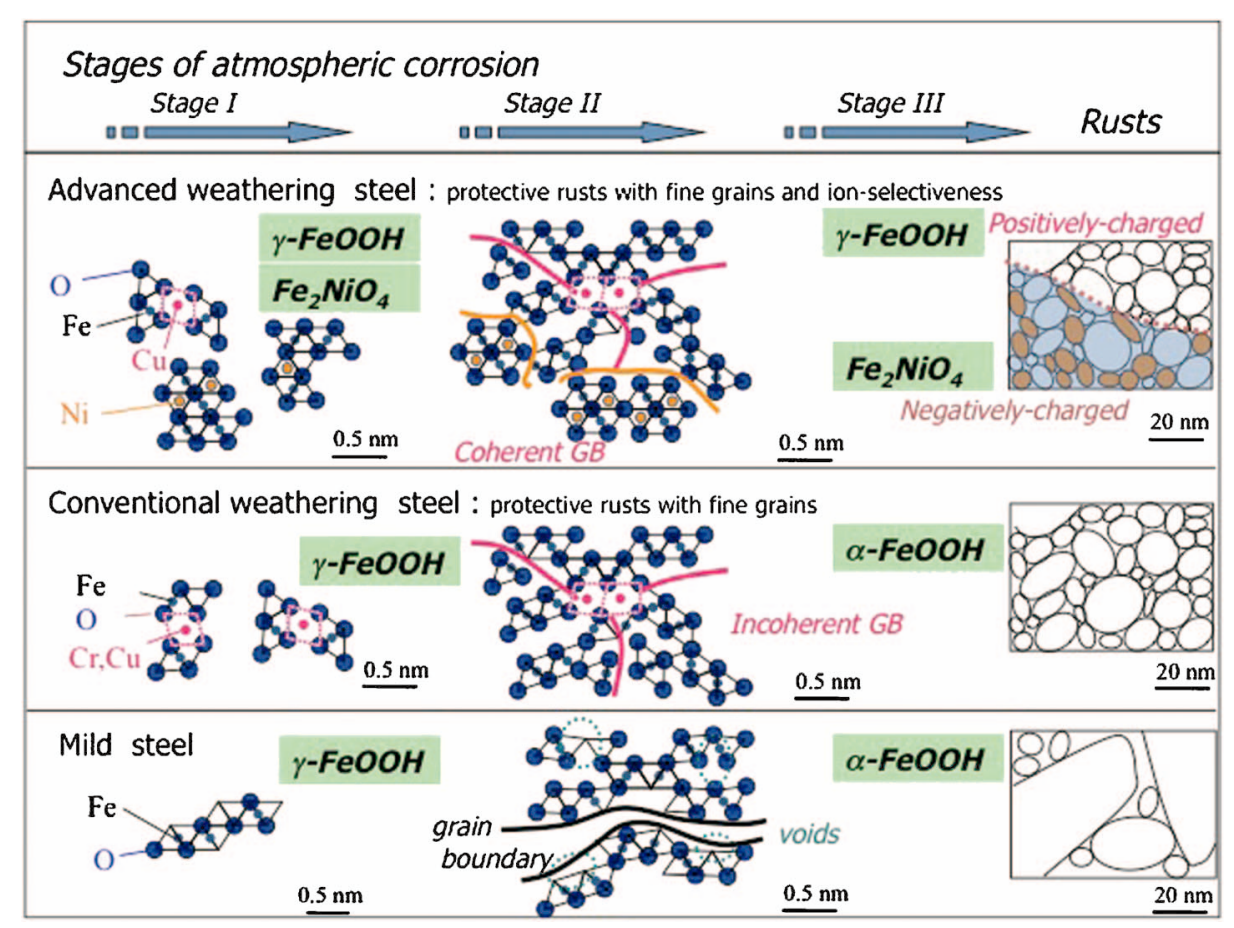

Fig. 7 (Color online) Schematic diagram of the evolution of the $\mathrm{Fe}(\mathrm{O}, \mathrm{OH})_{6}$ nano-network of rust formed on the advanced weathering steel in an atmosphere containing relatively high air-born salinity (above), which is compared to conventional weathering steel (middle), and mild steel (below) exposed in milder conditions ${ }^{9,10)}$. 
利用技術の開発により，低環境負荷により社会基盤インフラ を支える技術の提供が可能となった．

社会基盤インフラ材料の様に長期に使用する材料はもちろ 几，寿命は短期であっても充放電可能な電池のように使用中 に特性が大きく変化する材料では, 材料特性の安定性を如何 に制御するかが重要になる。そのためには様々な加速試験が 行われているが，その妥当性の検証や，経時変化の直接的検 証による本質的理解のためのアプローチが強く求められてい る. 劣化などの複雑な現象の理解には単一の手法での観察だ けでは不十分なことも多く, 複数の「計測」手法によって反 応観察を行い, 得られる情報を総合化していくことが重要に なる。

ここで紹介した研究例は観察の領域（X 線の照射領域） が $\mathrm{mm}$ オーダーと大きいために, 試料中で進行する反応の “平均值”を測定することができ，測定視野や試料を変えた 実験を行っても再現性良く反応を観察できた。そのため, XAS とXRD を同時に測定した場合と，個別に測定しても その結果はほぼ同一であり, 必要に応じてその測定法を使い 分けた（同時の測定では，実験上の制約でそれぞれの手法の ベストの条件で測定できないケースもあるため)。しかし， 次章に述べるように，「空間の heterogeneity」を複数の手法 で測定する場合には，複数の「計測」を同時に測定すること が必須である場合もあり，実験的にはさらにチャレンジにな る.

\section{4. 焼結鉱（Fe-Ca-O 系複合酸化物）の化学状 態マッピング}

反応観察の重要な次元として,「空間（3 次元）」の heterogeneity について最後に紹介したい. 反応に伴う構造や組 織の変化は多くの場合材料中で不均一であり，その heterogeneity の変化を含めた反応観察が，メカニズム解明やプ ロセス設計に重要となる. 本節では, 著者らの研究グループ の取り組反例として, 焼結鉱 $(\mathrm{Fe}-\mathrm{Ca}-\mathrm{O}$ 系複合酸化物）の 還元反応観察の例12,13)を紹介する.

鉄鋼製造の最重要プロセスのひとつである製銑プロセスで は，鉄鉱石を液相焼結により融着させた焼結鉱を還元性の $\mathrm{CO}$ ガスで還元する. 粒子サイズが数 $\mathrm{mm}$ 数 $10 \mathrm{~mm}$ である 焼結鉱は, 種々の $\mathrm{Fe}$ 酸化物 $\left(\alpha-\mathrm{Fe}_{2} \mathrm{O}_{3}, \mathrm{Fe}_{3} \mathrm{O}_{4}\right)$ 打よび種々 のカルシウムフェライト $\left(\mathrm{CaFe}_{2} \mathrm{O}_{4}, \mathrm{Ca}_{2} \mathrm{Fe}_{2} \mathrm{O}_{5}\right.$ 等 $)$ から構 成されており，それらの微細組織（microstructure）の間に サブ $\mu \mathrm{m}$ 数 $\mathrm{mm}$ の気孔網が存在している，その通気網内の 還元性ガスの流れと, 酸化物およびカルシウムフェライト相 からなる微細組織が，焼結鉱の還元挙動に大きな影響を与え る. その過程を理解し制御するためには，各相のバルクとし ての理想的な還元速度だけでなく, 焼結鉱内の微細組織の中 でどのように不均一に還元反応が進行するかを観察する必要 がある。

放射光からのX 線ビーム(直径約 $20 \mu \mathrm{m}$ )を試料に照射し， XAS 抢よびXRD の測定から，鉄の化学状態（価数等の電 子状態抢よび鉄原子周りの局所構造）と結晶構造を同視野測 定する光学系 (Fig. 6 (b)) での測定を, KEK, PF, BL$15 \mathrm{~A} 1^{14,15)}$ で行った。蛍光 $\mathrm{X}$ 線を検出しながら試料位置を走 (a)

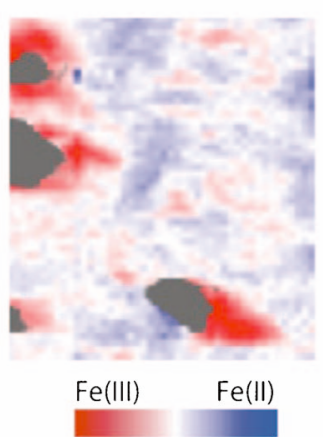

(b)

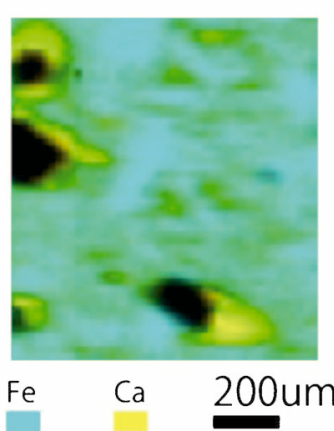

Fig. 8 (Color online) Two dimensional mapping of a partially-reduced iron sinter: (a) chemical state of iron, and (b) compositions of $\mathrm{Fe}$, and $\mathrm{Ca}$.

査, さらに光エネルギーを $\mathrm{Fe} K$ 端の周りで変化させること で, $\mathrm{Fe}$ や $\mathrm{Ca}$ の分布，さらに $\mathrm{Fe}$ の価数の情報を同視野測定 した．還元途中の焼結鉱の測定例を Fig. 8 に示す. Fig. 8 (a)は, 鉄の 3〜2 価の価数分布を示しており, 空白は $\mathrm{Fe}$ の 蛍光 X 線強度が少ない，すなわち空孔の領域（通気網の一 部）を表す．Fig. 8（b)は，鉄抢よびカルシウムの元素濃度 を示す，両者の結果から，必ずしもマクロ的な大きな孔（気 孔網）の付近から還元が進行するのでは無く， Ca 濃度の少 ない部分から還元が進行することが明らかになった．還元の 程度の異なる試料についてこうした観察を行うことにより, 焼結鉱の還元プロセスを明らかにすることができ，効率的な 還元プロセスのための指針につながる基礎的情報を提供する ことができる.

さらにX 線 computed tomography（CT 法）を併用する ことにより，化学状態の 3 次元観察が可能となる. 具体的 には, 測定する元素の吸収端近傍の X 線が透過する程度す で試料のサイズを小さくし（今回の焼結鉱試料では $10-20$ $\mu \mathrm{m}$ 程度), 試料を回転させながら透過 X線を用いて同様の 測定を行い，得られた透過像の再構成を行う。これにより， 化学状態や組織等の「空間 (3 次元)」の heterogeneity に関 する情報をさらに測定可能になる。

現状の放射光を用いればこうした測定を数 10 分程度の時 間で測定可能である．そのため比較的ゆっくりと進行する反 応であれば，エネルギー可変の「計測（エネルギー軸）」に より化学状態を観察する手法に扔いて,「空間 $(2 \sim 3$ 次元 $) 」$ での heterogeneity を，「反応条件」「時間」を変えて測定す ることも可能であり, 触媒や電池等の様々な系での研究が近 年盛んになってきている16-19)。な抢，本稿では X 線のエネ ルギーが $10 \mathrm{keV}$ 前後の領域に限って紹介したが, 軟 $\mathrm{X}$ 線の 領域では, 二次元の化学状態マッピング技術（X-ray scanning transmission X-ray microscopy (STXM), 例えば20,21)) が確立され，炭素系材料や有機物材料に広く展開されている.

反応に伴う構造の変化は多くの場合材料中で不均一である ことがほとんどであることを考えると，「反応条件」「時間」 「計測（エネルギー軸，回折角度軸，…)」「空間（3 次元）」 の 6 次元の反応観察は, 材料の製造 - 開発, 機能発現入力 ニズムの解明，機能の劣化や経時変化の観察，のすべての局 面で重要な情報を得るために欠くことのできない反応観察技 
術としてこれからの発展が期待できる.

\section{5. おわりに}

本稿では，XAS 法を用いて反応を観察するために重要と なるポイントである「反応条件」「時間」「計測」「空間（3 次元)」 heterogeneity, について, 具体例を通じて紹介し た.これらの各軸（視点）からの反応観察は, 手法開発から 材料開発への応用フェーズに入りつつある.こうした手法を 活用することにより，材料の製造・開発から，機能発現メ力 ニズムの解明, そして機能の劣化や経時変化に至る, 材料の 一生を理解し制御するために大きく役立つと期待できる。 そ れにより，例えば，“必要最小限のエネルギーと資源を用い て，必要最低限の機能（スペック）を有する材料を開発”と いった, 従来にない視点からの材料開発を展開できると考え ている.

最後にこうした多次元の計測を行う際に新たに課題となる ビッグデータの取り扱いについてコメントしたい。例えば, ある試料を $100 \times 100 \times 100$ の三次元の領域に分割し, 各領域 で100ステップのエネルギーステップの XAS スペクトルを 測定し，それを100ステップの時間で測定するとする。する と 1 つの粗測定のデーターサイズは， $10^{10}=10 \mathrm{G}$ になる. さらに空間分解能をあげるために $1000 \times 1000 \times 1000$ の分割 で測定したとすると，データサイズは $10^{13}=10 \mathrm{~T}$ にな. こうした膨大なサイズのデータとなると，その扱い（コピー や保存）はもちろん，その解析方法も従来と全く異なったア プローチが必要になるのは明白である。つまり, 反応を観察 するためには, ハード面の進歩に加えて, ソフト的な進歩が 不可欠であり, 情報学や応用数学との連携無しには材料研究 が立ちゆかない時代がすぐそこに迫っているといっても過言 でないであろう。

\section{謝辞}

本研究は, 新日鐵住金侏と高エネルギー加速器研究機構の 共同研究として, 多くの方々の協力で実施されたものであ り，この場を借りて関係各位に感謝申し上げます。特に， 丹羽尉博氏, 武市泰男博士, 村尾玲子博士, 紀平寬博士, 上村賢一博士には共同研究者として大变お世話になりまし た. なた 4 節の研究の一部は, 内閣府 戦略的イノベーショ ン創造プログラム 革新的構造材料 ユニット D66（SIPIMASM）の一環として実施しました４ 4 章の研究の一部は Photon Factory Program Advisory Committee (Proposal No. 2014G707, 2015S2-002，2016S1-001）の承認の下で実
施しました。

\section{〔文献〕}

1) T. Matsushita and R. P. Phizackerley: Jpn. J. Appl. Phys., 20 (1981) 2223.

2) Y. Inada, A. Suzuki, Y. Niwa and M. Nomura: AIP Conf. Proc., 879 (2006) 1230.

3) M. Kimura, K. Uemura, T. Nagai, Y. Niwa, Y. Inada and M. Nomura: J. Phys. Conf. Ser., 190 (2009) 012163.

4) M. Kimura, Y. Niwa, K. Uemura, T. Nagai, Y. Inada and M. Nomura: Mater. Trans., 54 (2013) 246.

5) K. Uemura, T. Nagai, M. Kimura, W. Ito and M. Kasuya: Proc. Society of Automobile Engineers of Japan, No.80-08 (2008) 19.

6) K. H. Kim, J. G. Kim, S. Nozawa, T. Sato, K. Y. Oang, T. W. Kim, H. Ki, J. Jo, S. Park, C. Song, T. Sato, K. Ogawa, T. Togashi, K. Tono, M. Yabashi, T. Ishikawa, J. Kim, R. Ryoo, J. Kim, H. Ihee and S. Adachi: Nature, 518 (2015) 385.

7) K. Ichiyanagi and K. G. Nakamura: Metals, 6 (2016) 17.

8) Y. Niwa, T. Sato, K. Ichiyanagi, K. Takahashi and M. Kimura: High Pressure Research, 36 (2016) 471.

9) M. Kimura, H. Kihira, N. Ohta, M. Hashimoto and T. Senuma: Corros. Sci., 47 (2005) 2499.

10) M. Kimura, T. Suzuki, G. Shigesato, M. Saito, S. Suzuki, H. Kihira, K. Tanabe and Y. Waseda: J. Japan Inst. Metals, 66 (2002) 166.

11) M. Kimura, T. Mizoguchi, H. Kihira and M. Kaneko: Characterization of Corrosion Products on Steel Surfaces, ed. Y. Waseda and S. Suzuki (Springer, 2006) chapter 11, p. 245.

12) M. Kimura, Y. Uemura, T. Takayama, R. Murao, K. Asakura and M. Nomura: J. Phys. Conf. Ser., 430 (2013) 012074.

13) M. Kimura, R. Murao, N. Ohta, K. Noami, Y. Uemura, Y. Niwa, K. Kimijima, Y. Takeichi and H. Nitani: J. Phys. Conf. Ser., 712 (2016) 012077.

14) N. Igarashi, N. Shimizu, A. Koyama, T. Mori, H. Ohta, Y. Niwa, H. Nitani, H. Abe, M. Nomura and T. Shioya: J. Phys. Conf. Ser., 425 (2013) 072016.

15) N. Igarashi, H. Nitani, Y. Takeichi, Y. Niwa, H. Abe, M. Kimura, T. Mori, Y. Nagatani, T. Kosuge and A. Kamijo: AIP Conf. Proc., 1741 (2016) 040021.

16) F. Meirer, J. Cabana, Y. Liu, A. Mehta, J. C. Andrews and P. Pianetta: J. Synchrotron Rad., 18 (2011) 773.

17) Y. Liu, F. Meirer, J. Wang, G. Requena, P. Williams, J. Nelson, A. Mehta, J. C. Andrews and P. Pianetta: Anal. Bioanal. Chem., 404 (2012) 1297.

18) T. Saida, O. Sekizawa, N. Ishiguro, M. Hoshino, K. Uesugi, T. Uruga, S. Ohkoshi, T. Yokoyama and M. Tada: Angew. Chem. Int. Ed. Engl., 51 (2012) 10311.

19) S. Bauer, L. de Biasi, S. Glatthaar, L. Toukam, H. Geßswein and T. Baumbach: Phys. Chem. Chem. Phys., 17 (2015) 16388.

20) Y. Takeichi, N. Inami, H. Suga, C. Miyamoto, T. Ueno, K. Mase, Y. Takahashi and K. Ono: Rev. Sci. Instrum., 87 (2016) 013704.

21) Y. Takeichi, N. Inami, H. Suga, K. Ono and Y. Takahashi: Chem. Lett., 43 (2014) 373. 